\title{
Controlled Deterioration
} and Accelerated Aging Tests Predict Relative Seedling Emergence Potential of Melon Seed Lots

\author{
Kazim Mavi and Ibrahim Demir ${ }^{1}$ \\ University of Ankara, Faculty of Agriculture, Department of Horticulture \\ 06110 Diskapi, Ankara, Turkey
}

Additional index words. melon, Cucumis melo L., seed vigor, seedling emergence

\begin{abstract}
The emergence of 22 commercial seed lots (12 in 2005 and 10 in 2006) of melon (Cucumis melo L.) with laboratory germinations greater than $90 \%$ were compared in low temperature (LTE), mechanical stress (MSE), high temperature (HTE), and salt stress (SSE) sowing conditions. The seedling emergence percentage ranged between $18 \%$ and $79 \%$ for LTE, $15 \%$ and $90 \%$ for MSE, $27 \%$ and $84 \%$ for HTE, and $49 \%$ and $92 \%$ for SSE in 2005; and $43 \%$ and $85 \%$ for LTE, $30 \%$ and $82 \%$ for MSE, $56 \%$ and $91 \%$ for HTE, and $49 \%$ and $89 \%$ for SSE in 2006 . The germination of the lots was determined after controlled deterioration (CD) with $20 \%$ or $24 \%$ moisture content (MC) and accelerated aging (AA) at 40 and $45^{\circ} \mathrm{C}$ in 2005; or at 45 and $47^{\circ} \mathrm{C}$ in 2006 for 48, 72, 96, 120, and $144 \mathrm{~h}$. Germination after various combinations of $C D$ and $A A$ was positively and significantly $(P<0.05)$ correlated with LTE, MSE, HTE, and SSE. Correlation values $(0.17$ to 0.78$)$ of the initial laboratory germination were much lower than those of both aging tests. The optimum CD conditions of $48 \mathrm{~h}$ and $20 \% \mathrm{MC}$ at $45^{\circ} \mathrm{C}$ and $\mathrm{AA}$ conditions of $120 \mathrm{~h}$ at 45 to $47^{\circ} \mathrm{C}$ are suggested as vigor tests to estimate relative seedling emergence of melon seeds.
\end{abstract}

Obtaining optimum and uniform plant stands in the field requires rapid seedling emergence. Various environmental stress factors such as low and high temperatures, mechanical stress, and high salinity affect emergence during stand establishment in melon seeds. Melon seeds are either sown directly or as transplants. Although the optimum temperature for melon seed germination is between 25 and $35{ }^{\circ} \mathrm{C}$ (Bates and Robinson, 1995), during transplant production in modules, the temperature range is often suboptimal for germination in early spring in the Mediterranean region. Seeds are sown deeper $(7$ to $8 \mathrm{~cm}$ ) in open field direct planting, which allows seeds to use water retained beneath the soil during germination. Then, the germinating seeds are likely to encounter mechanical resistance until they appear to the soil surface. Saline seedbed conditions resulting from aridity or use of saline groundwater can delay and increase the spread of seed germination in the field (Foolad and Lin, 1997).

When field conditions are near optimum, the standard germination may predict relative seedling emergence potential of the lot in the field. However, field conditions are often suboptimal. Seed vigor is composed of var-

\footnotetext{
Received for publication 28 Feb. 2007. Accepted for publication 21 May 2007.

We express our gratitude to The Scientific and Technological Research Council of Turkey (TUBITAK) for supporting the research.

${ }^{1}$ To whom reprint requests should be addressed; e-maildemir@agri.ankara.edu.tr.
}

ious features of seed quality and is indicative of seed lot performance beyond standard laboratory germination. Vigor tests provide additional information on the rate and uniformity of seedling growth and emergence ability under a wide range of environmental conditions (Powell and Matthews, 2005; TeKrony, 2003).

The controlled deterioration (CD) (Powell and Matthews, 2005) and accelerated aging (AA) (Hampton and TeKrony, 1995) tests have been successfully used to rank and predict relative field emergence potential of seed lots in various crops such as brassicas, onion, carrot (Matthews, 1980; Powell and Matthews, 1981), red clover (Wang et al., 1994), aubergine (Demir et al., 2005), sorghum (Ibrahim et al., 1993), and corn (Bennett et al., 2004; TeKrony et al., 1989). Seeds are subjected to high temperature (40 to 45 ${ }^{\circ} \mathrm{C}$ ) at high relative humidity (greater than $95 \%$ ) in AA or with prearranged high seed moisture content ( $18 \%$ to $24 \%$ ) in CD for 24 to $96 \mathrm{~h}$ before germination testing. It was proposed that environment of $45^{\circ} \mathrm{C}$ and $20 \%$ seed moisture content for $24 \mathrm{~h}$ in $\mathrm{CD}$ and 41 to $43{ }^{\circ} \mathrm{C}$ for 24 to $72 \mathrm{~h}$ in $\mathrm{AA}$ is applicable for a large number of species (Hampton and TeKrony, 1995; Matthews, 1993). However, the most appropriate aging environment needs to be determined for each species. $\mathrm{CD}$ and $\mathrm{AA}$ studies for evaluating vigor and estimating seedling emergence in cucurbit seeds are scarce. Some of the earlier studies indicated that optimum aging conditions varied among cucurbit species such as watermelon (Delouche and Baskin, 1973) melon (Demir et al., 2004; Pesis and Timothy, 1983;
Torres and Marcos-Filho, 2005), pumpkin, and zucchini (Dutra and Vieira, 2006). Most of these studies determined the ranking of the seed lots but did not correlate aging tests results with seedling emergence.

The objective of the present research was to evaluate the conditions for application of $\mathrm{CD}$ and $\mathrm{AA}$ tests in melon seeds, seeking to associate (i.e., predict) results with not actual but relative seedling emergence potential of seed lots in low and high temperature, mechanical and salt stress sowing conditions.

\section{Materials and Methods}

Twelve seed lots in 2005 and 10 in 2006 of melon (Cucumis melo L.), variety Kurkagac, were obtained from various commercial sources in Turkey.

The germination of four replicates of 50 seeds from each seed lot was assessed using the between-paper method [International Seed Testing Association (ISTA), 2003] at $25^{\circ} \mathrm{C}$ in the dark. The percentage of normal seedlings (ISTA, 2003) was determined after $8 \mathrm{~d}$. Seed moisture content was determined using the high-temperature oven $\left(130^{\circ} \mathrm{C}, 1 \mathrm{~h}\right)$ method (ISTA, 2003).

The CD test was conducted on samples of the seed lots held at $20 \%$ and $24 \%$ seed moisture contents (MC) for 48, 72, 96, 120, and $144 \mathrm{~h}$ at 40 and $45^{\circ} \mathrm{C}$ in 2005 and 45 and $47^{\circ} \mathrm{C}$ in 2006 . For each temperature and seed moisture combination of each lot, two batches of 800 seeds of known initial moisture content were placed on moist paper and allowed to imbibe to the weight calculated to achieve a $20 \% \mathrm{MC}$ for one batch and $24 \%$ $\mathrm{MC}$ for the other. The achievement of this weight was determined by periodic weighing of the batches. Seeds were then kept at $5{ }^{\circ} \mathrm{C}$ in laminated foil bags for $72 \mathrm{~h}$ to allow moisture equilibration within and among the seeds. Subsamples of 150 seeds/lot/test moisture content/test temperature were sealed in airproof laminated foil bags and incubated at appropriate temperature and aging time. Germination (2-mm radicle emergence) was then tested.

The accelerated aging test was conducted according to the procedure described by Hampton and TeKrony (1995) with modifications for melon. Forty milliliters of distilled water was added to each plastic box $(11 \times 11 \times 4 \mathrm{~cm})$. One hundred fifty seeds were put on a wire mesh tray $(10 \times 10 \times 3 \mathrm{~cm})$ and placed in the box. One box was used for each temperature and time combination in each lot. Seeds were aged at $40 \pm 0.1^{\circ} \mathrm{C}$ or 45 $\pm 0.1^{\circ} \mathrm{C}$ in 2005 , and 45 or $47^{\circ} \mathrm{C}$ in 2006 , for $48,72,96,120$, and $144 \mathrm{~h}$ in a water-jacketed incubator. After every aging period, seeds were removed, weighed, and the final seed moisture was calculated according to weight they had reached. The germination test was conducted as described after $3 \mathrm{~h}$ of drying at room temperature. The radicle protrusion (physiological germination) was the criterion of germination used.

For the low temperature emergence test (LTE), seeds (four replicates of 50 seeds/lot) were sown $3 \mathrm{~cm}$ deep in the experimental 
field of the Department of Horticulture, Faculty of Agriculture, University of Ankara, Turkey, on 15 Apr. 2005 and 22 Apr. 2006. For high temperature emergence test (HTE), seeds were sown on 15 Aug. 2005 and 18 Aug. 2006. The soil was a sandy loam (pH 7.57, N: $0.09, \mathrm{P}_{2} \mathrm{O}_{5}: 5.5 \%, \mathrm{~K}: 0.16 \%, \mathrm{Na}$ : $0.41 \%$, Ca: $6.7 \%$, organic matter: $1.1 \%$ ). Daily minimum and maximum soil temperatures were recorded throughout both tests and varied between 9 and $27^{\circ} \mathrm{C}$ in LTE and 25 and $39{ }^{\circ} \mathrm{C}$ in HTE. The number of seedlings emerged, assessed to have occurred when the cotyledons had unfolded above the surface, was counted daily and finally after $30 \mathrm{~d}$ in LTE and $20 \mathrm{~d}$ in HTE.

The mechanical stress emergence test was carried out by sowing 200 (four replicates of 50 seeds) seeds $8 \mathrm{~cm}$ deep on 15 May 2005 and 1 June 2006 in the same field. Depth of sowing was determined by measuring and planting seeds by hand at the same level. Subsequently, irrigation was done regularly three times a week and weeds were removed. Daily minimum and maximum soil temperature varied between 18 and $30^{\circ} \mathrm{C}$ during this test. The seedling emergence criterion was the same as in the previous tests.

Seedling emergence under salt stress was determined by sowing seeds $4 \mathrm{~cm}$ deep in compost (Plantaflour, Humus-Verkaufs $\mathrm{GmbH}$, Germany) in plastic seedling trays $(32 \times 6 \times 6 \mathrm{~cm})$. The electrical conductivity of the saturated extract of the compost was $0.8 \mathrm{mS} \cdot \mathrm{cm}^{-1}$ before sowing. The trays were placed on a bench in a growing cabinet in which the temperature was maintained at $20 \pm 2{ }^{\circ} \mathrm{C}$ and salinity was provided by the solution that was used to water the seeds ( 200 $\mathrm{mm}, \mathrm{NaCl}$ ). Trays were covered with paper until emergence. Subsequently, light was provided at seedling level by cool fluorescent lamps $\left(72 \mu \mathrm{M} \cdot \mathrm{m}^{-1} \cdot \mathrm{s}^{-1}\right)$. Trays were inspected daily, and the relative humidity in the cabinet was kept over $75 \%$ to keep evaporation at a minimum. Trays were watered with the same amount of saline solution $(100 \mathrm{~mL})$ as needed. The experiment was ended $25 \mathrm{~d}$ after sowing.

\section{Results}

Initial standard germination percentages of lots ranged between $90 \%$ and $100 \%$ in 2005 and $95 \%$ and $99 \%$ in 2006. Seed moisture content ranged between $4.1 \%$ and $9.1 \%$ (Table 1).

In 2005, emergence at the LTE sowing ranged from $18 \%$ (lot 2$)$ to $79 \%$ (lot 10$)$, with various significant $(P<0.05)$ differences among lots (Table 2). In the mechanical stress (MSE), emergence ranged from 15\% to $85 \%$ and $27 \%$ to $84 \%$ in HTE, $49 \%$ to $92 \%$ in salt stress sowing (SSE), with lot 2 being the lowest emergence in all stress sowings (Table 2). Several lots in each stress emergence test showed differences in emergence, which were significant $(P<0.05)$, but lots 3 , $6,8,9$, and 10 showed higher emergences than other seed lots in most tests. The lowest emergence values were found in LTE and the highest in SSE, except for a few lots.
In 2006, the lowest emerging lot was 1 and the highest one was 4 in LTE, MSE, HTE, and SSE sowings (Table 2). Several lots in all four stress environments showed differences in emergence that were significant $(P<0.05)$.

The final seedling emergence of the lots at low temperature, high temperature, mechan- ical and salt stresses in both years was positively correlated with $\mathrm{CD}$ germination. Significant correlations were found with emergence in each stress sowing test. However, $45{ }^{\circ} \mathrm{C}$ with $20 \% \mathrm{MC}$ for $48 \mathrm{~h}$ consistently gave very high correlation values in all four sowing environments in both years (Table 3 ).

Table 1. Initial standard germination (SG\%) and seed moisture (MC, fwt, \%) of melon seed lots used in 2 consecutive years.

\begin{tabular}{|c|c|c|c|c|c|}
\hline \multicolumn{3}{|c|}{2005} & \multicolumn{3}{|c|}{2006} \\
\hline Lot & SG $(\%)$ & S.m.c. (\%) & Lot & SG $(\%)$ & S.m.c. (\%) \\
\hline 1 & 100 & 7.3 & 1 & 97 & 7.5 \\
\hline 2 & 91 & 5.8 & 2 & 96 & 7.7 \\
\hline 3 & 99 & 5.6 & 3 & 96 & 6.5 \\
\hline 4 & 99 & 5.9 & 4 & 99 & 4.8 \\
\hline 5 & 91 & 8.1 & 5 & 96 & 7.8 \\
\hline 6 & 100 & 4.9 & 6 & 97 & 7.3 \\
\hline 7 & 99 & 4.9 & 7 & 97 & 6.9 \\
\hline 8 & 99 & 4.1 & 8 & 95 & 7.9 \\
\hline 9 & 96 & 9.1 & 9 & 96 & 7.4 \\
\hline 10 & 95 & 3.6 & 10 & 98 & 7.9 \\
\hline 11 & 90 & 8.0 & NA & NA & NA \\
\hline 12 & 95 & 7.4 & NA & NA & NA \\
\hline
\end{tabular}

$\mathrm{SG}=$ standard germination; S.m.c. $=$ seed moisture content; NA = not available.

Table 2. Seedling emergence at low temperature, mechanical stress, high temperature stress, and salt stress sowings in 2005 and $2006 .^{2}$

\begin{tabular}{|c|c|c|c|c|c|c|c|c|c|}
\hline \multicolumn{5}{|c|}{2005} & \multicolumn{5}{|c|}{2006} \\
\hline Lots & LTE & MSE & HTE & SSE & $\overline{\text { Lots }}$ & LTE & MSE & HTE & $\overline{\text { SSE }}$ \\
\hline 1 & $55 \mathrm{bc}$ & $57 \mathrm{~b}$ & $70 \mathrm{abc}$ & $79 b$ & 1 & $43 \mathrm{~d}$ & $30 \mathrm{~g}$ & $56 \mathrm{c}$ & $49 \mathrm{e}$ \\
\hline 2 & $18 \mathrm{f}$ & $15 \mathrm{~d}$ & $27 \mathrm{~d}$ & $49 \mathrm{~d}$ & 2 & $58 \mathrm{bcd}$ & $62 \mathrm{de}$ & $72 \mathrm{bc}$ & $64 \mathrm{~cd}$ \\
\hline 3 & $50 \mathrm{bcd}$ & $81 \mathrm{a}$ & $79 \mathrm{ab}$ & $91 \mathrm{a}$ & 3 & $51 \mathrm{~cd}$ & $41 \mathrm{f}$ & $65 \mathrm{bc}$ & $56 \mathrm{de}$ \\
\hline 4 & $40 \mathrm{de}$ & $50 \mathrm{~b}$ & $64 \mathrm{bc}$ & $88 \mathrm{ab}$ & 4 & $85 \mathrm{a}$ & $82 \mathrm{a}$ & $91 \mathrm{a}$ & $89 \mathrm{a}$ \\
\hline 5 & $52 \mathrm{bcd}$ & $46 \mathrm{~b}$ & $74 \mathrm{abc}$ & $63 \mathrm{c}$ & 5 & $63 \mathrm{bc}$ & $61 \mathrm{de}$ & $78 \mathrm{~b}$ & $72 \mathrm{bc}$ \\
\hline 6 & $63 \mathrm{~b}$ & $82 \mathrm{a}$ & $77 \mathrm{ab}$ & $92 \mathrm{a}$ & 6 & $69 \mathrm{~b}$ & $78 \mathrm{ab}$ & $78 \mathrm{~b}$ & $84 \mathrm{a}$ \\
\hline 7 & $48 \mathrm{~cd}$ & $51 \mathrm{~b}$ & $66 \mathrm{bc}$ & $79 \mathrm{~b}$ & 7 & $69 \mathrm{~b}$ & $68 \mathrm{~cd}$ & $75 \mathrm{~b}$ & $61 \mathrm{cde}$ \\
\hline 8 & $61 \mathrm{~b}$ & $90 \mathrm{a}$ & $84 \mathrm{a}$ & $88 \mathrm{ab}$ & 8 & $62 \mathrm{bc}$ & $75 \mathrm{bc}$ & $76 \mathrm{~b}$ & $80 \mathrm{ab}$ \\
\hline 9 & $76 \mathrm{a}$ & $83 \mathrm{a}$ & $70 \mathrm{abc}$ & $89 a b$ & 9 & $59 \mathrm{bcd}$ & $59 \mathrm{e}$ & $75 \mathrm{~b}$ & $64 \mathrm{~cd}$ \\
\hline 10 & $79 \mathrm{a}$ & $85 \mathrm{a}$ & $71 \mathrm{abc}$ & $91 \mathrm{a}$ & 10 & $62 \mathrm{bc}$ & $55 \mathrm{e}$ & $74 \mathrm{~b}$ & $59 \mathrm{cde}$ \\
\hline 11 & $32 \mathrm{e}$ & $29 \mathrm{c}$ & $56 \mathrm{c}$ & $61 \mathrm{c}$ & NA & NA & NA & NA & NA \\
\hline 12 & $46 \mathrm{~cd}$ & $55 \mathrm{~b}$ & $58 \mathrm{c}$ & $60 \mathrm{c}$ & NA & NA & NA & NA & NA \\
\hline
\end{tabular}

${ }^{z}$ Means with different letters are significantly $(P=0.05)$ different in the same column.

Emergence $(\%)$ at LTE = low temperature; MSE = mechanical stress; HTE = high temperature; $\mathrm{SSE}=\mathrm{salt}$ stress; NA $=$ not available.

Table 3. Correlation coefficient values calculated for laboratory germination and controlled deterioration test as predictors of melon seedling emergence percentages at low temperature (LTE), mechanical (MSE), high temperature stress (HTE), and salt stress (SSE) sowings in 2005 and 2006.

\begin{tabular}{|c|c|c|c|c|c|c|c|c|c|c|c|c|c|}
\hline \multicolumn{7}{|c|}{2005} & \multicolumn{7}{|c|}{2006} \\
\hline Temp & S.m.c. & Period & LTE & MSE & HTE & $\mathrm{SSE}$ & Temp & S.m.c. & Period & LTE & MSE & HTE & $\mathrm{SSE}$ \\
\hline & & 48 & 0.66 & 0.74 & 0.92 & 0.77 & & & 48 & 0.86 & 0.96 & 0.90 & 0.92 \\
\hline & & 72 & 0.53 & 0.73 & 0.65 & 0.87 & & & 72 & 0.83 & 0.88 & 0.82 & 0.68 \\
\hline & $20 \%$ & 96 & 0.66 & 0.83 & 0.70 & 0.90 & & $20 \%$ & 96 & 0.86 & 0.89 & 0.93 & 0.84 \\
\hline & & 120 & 0.49 & 0.70 & 0.52 & 0.77 & & & 120 & 0.84 & 0.96 & 0.87 & 0.82 \\
\hline \multirow[t]{10}{*}{$40^{\circ} \mathrm{C}$} & & 144 & 0.56 & 0.75 & 0.64 & 0.81 & $45^{\circ} \mathrm{C}$ & & 144 & 0.80 & 0.91 & 0.84 & 0.80 \\
\hline & & 48 & 0.69 & 0.75 & 0.61 & 0.90 & & & 48 & 0.65 & 0.70 & 0.73 & 0.59 \\
\hline & & 72 & 0.72 & 0.82 & 0.80 & 0.88 & & & 72 & 0.90 & 0.93 & 0.89 & 0.77 \\
\hline & $24 \%$ & 96 & 0.70 & 0.82 & 0.76 & 0.93 & & $24 \%$ & 96 & 0.85 & 0.85 & 0.81 & 0.76 \\
\hline & & 120 & 0.73 & 0.76 & 0.79 & 0.79 & & & 120 & 0.89 & 0.85 & 0.94 & 0.78 \\
\hline & & 144 & 0.83 & 0.82 & 0.73 & 0.79 & & & 144 & 0.81 & 0.90 & 0.77 & 0.77 \\
\hline & & 48 & 0.71 & 0.86 & 0.80 & 0.90 & & & 48 & 0.79 & 0.83 & 0.81 & 0.66 \\
\hline & & 72 & 0.47 & 0.69 & 0.56 & 0.68 & & & 72 & 0.88 & 0.94 & 0.93 & 0.83 \\
\hline & $20 \%$ & 96 & 0.62 & 0.77 & 0.73 & 0.83 & & $20 \%$ & 96 & 0.88 & 0.93 & 0.90 & 0.80 \\
\hline & & 120 & 0.66 & 0.81 & 0.70 & 0.72 & & & 120 & 0.93 & 0.93 & 0.91 & 0.79 \\
\hline \multirow[t]{7}{*}{$45^{\circ} \mathrm{C}$} & & 144 & 0.53 & 0.67 & 0.54 & 0.61 & $47^{\circ} \mathrm{C}$ & & 144 & 0.93 & 0.94 & 0.92 & 0.78 \\
\hline & & 48 & 0.70 & 0.81 & 0.75 & 0.81 & & & 48 & 0.77 & 0.84 & 0.80 & 0.84 \\
\hline & & 72 & 0.64 & 0.75 & 0.57 & 0.61 & & & 72 & 0.87 & 0.93 & 0.92 & 0.86 \\
\hline & $24 \%$ & 96 & 0.64 & 0.78 & 0.54 & 0.77 & & $24 \%$ & 96 & 0.86 & 0.92 & 0.89 & 0.76 \\
\hline & & 120 & 0.63 & 0.75 & 0.47 & 0.70 & & & 120 & 0.86 & 0.96 & 0.92 & 0.87 \\
\hline & & 144 & 0.75 & 0.85 & 0.65 & 0.78 & & & 144 & 0.84 & 0.79 & 0.86 & 0.60 \\
\hline & & SG & 0.42 & 0.63 & 0.59 & 0.78 & & & SG & 0.54 & 0.17 & 0.38 & 0.18 \\
\hline
\end{tabular}

2005: $\mathrm{r} \geq 0.58, P<0.05 ; \mathrm{r} \geq 0.71, P<0.01 ; \mathrm{r} \geq 0.82, P<0.001 ; 2006: \mathrm{r} \geq 0.63, P<0.05 ; \mathrm{r} \geq 0.77$, $P<0.01 ; \mathrm{r} \geq 0.87, P<0.001$.

S.m.c. $=$ seed moisture content. 
A large number of time and temperature combinations after AA were also significantly correlated with stressed emergence (Table 4). The highest values were observed after $120 \mathrm{~h}$ at $45^{\circ} \mathrm{C}$ in 2005 and at $47{ }^{\circ} \mathrm{C}$ in 2006. Correlation values between emergence in four different environment sowings in both years and germination after these accelerated aging conditions were consistently significant $\left(\mathrm{R}^{2}=0.71-0.85\right.$, five at $P<0.01$, three at $P<0.05$ ). As indicated in Tables 5 and 6 , the range of germination after various aging conditions for $\mathrm{AA}$ and $\mathrm{CD}$ tests increased with increasing time in the aging conditions. The range was widened as seeds were aged longer.

The standard germination correlated with emergence in some stress conditions such as MSE and SSE in 2005, but failed to correlate significantly $(P>0.05)$ in only three instances for the eight sowings over 2 years. The correlations with standard germination were much lower than those for aging conditions we proposed (Tables 3 and 4).

Germination after $\mathrm{CD}\left(45^{\circ} \mathrm{C}, 20 \%, 48 \mathrm{~h}\right)$ in both years and AA $\left(45^{\circ} \mathrm{C}, 120 \mathrm{~h}\right.$ in 2005 ; $47{ }^{\circ} \mathrm{C} 120 \mathrm{~h}$ in 2006) were significantly related to emergence at LTE, HTE, MSE, and SSE. The $\mathrm{R}^{2}$ values of aging test environments ranged from 0.49 to 0.91 . The lower the $\mathrm{CD}$ and $\mathrm{AA}$ germination for the lots, the lower their emergence at low and high temperatures and in mechanical and salt stress conditions. Laboratory germination was only significantly correlated with MSE $\left(\mathrm{R}^{2}=0.40, P<0.05\right)$, SSE $\left(\mathrm{R}^{2}=0.60, P<\right.$ $0.01)$, and HTE $\left(\mathrm{R}^{2}=0.35, P<0.05\right)$ in 2005 , but it showed very low $\mathrm{R}^{2}$ and insignificant values $\left(\mathrm{R}^{2}=0.03-0.29, P>0.05\right)$ in the rest (Fig. 1). The separation of lots after aging was always greater than that for standard germination.

\section{Discussion}

The results of the present work indicated that CD and AA tests not only successfully ranked seed lots, but also predicted relative seedling emergence potential of melon seed lots under stress conditions. The best temperature, time, and aging durations were found as $45{ }^{\circ} \mathrm{C}$, with $20 \%$ for $48 \mathrm{~h}$ in $\mathrm{CD}, 45$ to $47{ }^{\circ} \mathrm{C}, 120 \mathrm{~h}$ in the AA test. Laboratory germination estimated emergence potential in some (2005 results), but its correlation values were lower than aging tests in most cases (Tables 3 and 4).

The CD test has been proposed to be a more suitable vigor test for small seeds (Powell and Matthews, 2005). Successful prediction of relative seedling emergence percentages in the field or in plug trays by $\mathrm{CD}$ test were in agreement with the conclusions of a number of studies, particularly in small-seeded vegetables (Basak et al., 2006; Demir et al., 2005; Strydom and Van de Venter, 1998), grass, and cereals seeds (Marshall and Naylor, 1985; Steiner and Stahl, 2002; Wang et al., 1994). Matthews (1993) proposed that $45^{\circ} \mathrm{C}$ with $20 \% \mathrm{MC}$ for $24 \mathrm{~h}$ can be a universal aging regime for small-

Table 4. Correlation coefficients calculated for laboratory germination and the accelerated aging test as predictors of melon seedling emergence percentages at low temperature (LTE), mechanical (MSE), high temperature (HTE), and salt stress (SSE) sowings in 2005 and 2006.

\begin{tabular}{|c|c|c|c|c|c|c|c|c|c|c|c|}
\hline \multicolumn{6}{|c|}{2005} & \multicolumn{6}{|c|}{2006} \\
\hline Temp. & Period (h) & LTE & MSE & HTE & $\overline{\mathrm{SSE}}$ & Temp. & Period (h) & LTE & MSE & HTE & $\mathrm{SSE}$ \\
\hline & 48 & 0.36 & 0.61 & 0.42 & 0.76 & & 48 & 0.33 & 0.25 & 0.35 & 0.04 \\
\hline & 72 & 0.31 & 0.56 & 0.43 & 0.76 & & 72 & 0.49 & 0.40 & 0.41 & 0.14 \\
\hline \multirow[t]{5}{*}{$40^{\circ} \mathrm{C}$} & 96 & 0.48 & 0.68 & 0.61 & 0.85 & $45^{\circ} \mathrm{C}$ & 96 & 0.67 & 0.40 & 0.63 & 0.33 \\
\hline & 120 & 0.67 & 0.78 & 0.83 & 0.91 & & 120 & 0.44 & 0.50 & 0.41 & 0.29 \\
\hline & 144 & 0.66 & 0.74 & 0.68 & 0.87 & & 144 & 0.79 & 0.64 & 0.73 & 0.50 \\
\hline & 48 & 0.45 & 0.70 & 0.70 & 0.79 & & 48 & 0.60 & 0.57 & 0.67 & 0.36 \\
\hline & 72 & 0.57 & 0.75 & 0.62 & 0.85 & & 72 & 0.71 & 0.52 & 0.70 & 0.31 \\
\hline \multirow[t]{4}{*}{$45^{\circ} \mathrm{C}$} & 96 & 0.60 & 0.77 & 0.69 & 0.81 & $47^{\circ} \mathrm{C}$ & 96 & 0.59 & 0.74 & 0.48 & 0.70 \\
\hline & 120 & 0.71 & 0.77 & 0.74 & 0.85 & & 120 & 0.80 & 0.72 & 0.72 & 0.71 \\
\hline & 144 & 0.50 & 0.59 & 0.40 & 0.68 & & 144 & 0.68 & 0.61 & 0.63 & 0.62 \\
\hline & SG & 0.42 & 0.63 & 0.59 & 0.78 & & SG & 0.54 & 0.17 & 0.38 & 0.18 \\
\hline
\end{tabular}

2005: $\mathrm{r} \geq 0.58, P<0.05 ; \mathrm{r} \geq 0.71, P<0.01 ; \mathrm{r} \geq 0.82, P<0.001 ; 2006: \mathrm{r} \geq 0.63, P<0.05 ; \mathrm{r} \geq 0.77$, $P<0.01 ; \mathrm{r} \geq 0.87, P<0.001$.

Table 5. Maximum, minimum, and mean germination percentages of the melon seed lots after controlled deterioration test at $20 \%$ and $24 \%$ moisture content and aging temperature $\left(40\right.$ and $45{ }^{\circ} \mathrm{C}$ in 2005 ; 45 and $47^{\circ} \mathrm{C}$ in 2006) and periods (h).

\begin{tabular}{|c|c|c|c|c|c|c|c|c|c|}
\hline \multicolumn{5}{|c|}{2005} & \multicolumn{5}{|c|}{2006} \\
\hline $40^{\circ} \mathrm{C}$ & \multicolumn{2}{|c|}{$20 \%$} & \multicolumn{2}{|c|}{$24 \%$} & $45^{\circ} \mathrm{C}$ & \multicolumn{2}{|c|}{$20 \%$} & \multicolumn{2}{|c|}{$24 \%$} \\
\hline Hours & Range & Mean & Range & Mean & Hours & Range & Mean & Range & Mean \\
\hline 48 & $51-99$ & 88 & $47-96$ & 79 & 48 & 64-95 & 83 & $71-97$ & 85 \\
\hline 72 & $42-99$ & 81 & 39-97 & 81 & 72 & $60-93$ & 80 & $67-92$ & 82 \\
\hline 96 & 55-97 & 80 & $44-93$ & 77 & 96 & $60-96$ & 82 & $63-96$ & 78 \\
\hline 120 & $50-97$ & 76 & $37-93$ & 76 & 120 & $42-91$ & 73 & $52-90$ & 73 \\
\hline 144 & $39-100$ & 75 & $20-92$ & 66 & 144 & $20-85$ & 63 & $38-86$ & 63 \\
\hline$\overline{45^{\circ} \mathrm{C}}$ & \multicolumn{2}{|c|}{$20 \%$} & \multicolumn{2}{|c|}{$24 \%$} & $47^{\circ} \mathrm{C}$ & \multicolumn{2}{|c|}{$20 \%$} & \multicolumn{2}{|c|}{$24 \%$} \\
\hline Hours & Range & Mean & Range & Mean & Hours & Range & Mean & Range & Mean \\
\hline 48 & $45-99$ & 80 & $70-100$ & 88 & 48 & $60-96$ & 82 & 77-97 & 88 \\
\hline 72 & $49-100$ & 77 & $52-100$ & 84 & 72 & 57-93 & 81 & $62-94$ & 83 \\
\hline 96 & $22-99$ & 69 & $41-99$ & 76 & 96 & $43-92$ & 76 & $59-94$ & 82 \\
\hline 120 & 7-99 & 57 & $31-95$ & 67 & 120 & $43-89$ & 70 & $53-89$ & 76 \\
\hline 144 & $3-96$ & 51 & $14-92$ & 57 & 144 & $22-90$ & 62 & $48-84$ & 70 \\
\hline
\end{tabular}

Table 6. Maximum, minimum, and mean germination percentages of the melon seed lots after the accelerated aging test at various aging temperatures $\left(40\right.$ and $45^{\circ} \mathrm{C}$ in $2005 ; 45$ and $47^{\circ} \mathrm{C}$ in 2006$)$ and periods $(\mathrm{h}) .^{\mathrm{z}}$

\begin{tabular}{|c|c|c|c|c|c|c|c|c|c|}
\hline \multicolumn{5}{|c|}{2005} & \multicolumn{5}{|c|}{2006} \\
\hline $40^{\circ} \mathrm{C}$ & & & S.m.c. (\%) & & $45^{\circ} \mathrm{C}$ & & & S.m.c. (\%) & \\
\hline Hours & Range & Mean & Range & Mean & Hours & Range & Mean & Range & Mean \\
\hline 48 & $53-100$ & 88 & $16.1-21.8$ & 19.2 & 48 & $76-92$ & 85 & $17.4-20.1$ & 18.7 \\
\hline 72 & $58-100$ & 89 & $15.7-23.4$ & 20.0 & 72 & $75-91$ & 84 & $16.6-22.2$ & 19.1 \\
\hline 96 & $58-99$ & 86 & $12.5-23.2$ & 18.9 & 96 & $64-95$ & 82 & $15.4-23.6$ & 19.2 \\
\hline 120 & $59-100$ & 90 & $14.1-26.2$ & 19.1 & 120 & $51-91$ & 77 & $16.8-24.3$ & 19.7 \\
\hline 144 & $57-100$ & 85 & 16.7-28.9 & 21.5 & 144 & 34-95 & 69 & $17.8-26.0$ & 21.2 \\
\hline $45^{\circ} \mathrm{C}$ & & & S.m.c. (\%) & & $47^{\circ} \mathrm{C}$ & & & S.m.c. (\%) & \\
\hline Hours & Range & Mean & Range & Mean & Hours & Range & Mean & Range & Mean \\
\hline 48 & $62-100$ & 86 & $14.9-21.8$ & 19.4 & 48 & $78-95$ & 89 & $12.2-24.5$ & 18.0 \\
\hline 72 & $50-100$ & 85 & $15.0-23.9$ & 19.1 & 72 & $76-94$ & 86 & $12.6-20.7$ & 18.9 \\
\hline 96 & 34-99 & 81 & $14.6-21.7$ & 19.3 & 96 & $65-91$ & 79 & $15.6-26.7$ & 19.4 \\
\hline 120 & $30-98$ & 77 & $14.2-25.4$ & 19.6 & 120 & $55-94$ & 70 & $17.2-22.9$ & 19.9 \\
\hline 144 & 24-94 & 64 & 14.1-21.2 & 20.2 & 144 & $40-85$ & 62 & $16.3-24.6$ & 20.0 \\
\hline
\end{tabular}

${ }^{\mathrm{z}}$ Range and the mean values of seed moisture contents after each aging time were also shown.

S.m.c. $=$ seed moisture content.

seeded species. Our previous experience showed this aging environment is not sufficient to discriminate winter squash seed lots, particularly when the initial laboratory germination is very high (greater than 95\%) (Mavi and Demir, 2005). This obviously indicates that the optimum aging environment is a species-specific phenomenon and needs to be determined for each species.

The AA test was initially developed to determine seed storage potential (Delouche and Baskin, 1973); it has evolved into a commonly used seed vigor indicator for many large-seeded crops and has been successfully used in ranking the seed vigor of various crops (Hampton and Bell, 1989; Hampton et al., 2004; Hampton and TeKrony, 1995; TeKrony et al., 1989, 2005). Pesis and $\mathrm{Ng}$ (1983) reported that vigor of the two muskmelon varieties were not separated by aging at $45^{\circ} \mathrm{C} 100 \%$ relative humidity for $96 \mathrm{~h}$. However, extending the aging time to $192 \mathrm{~h}$ provided a good separation. Our results agree with this work. Extended aging period 


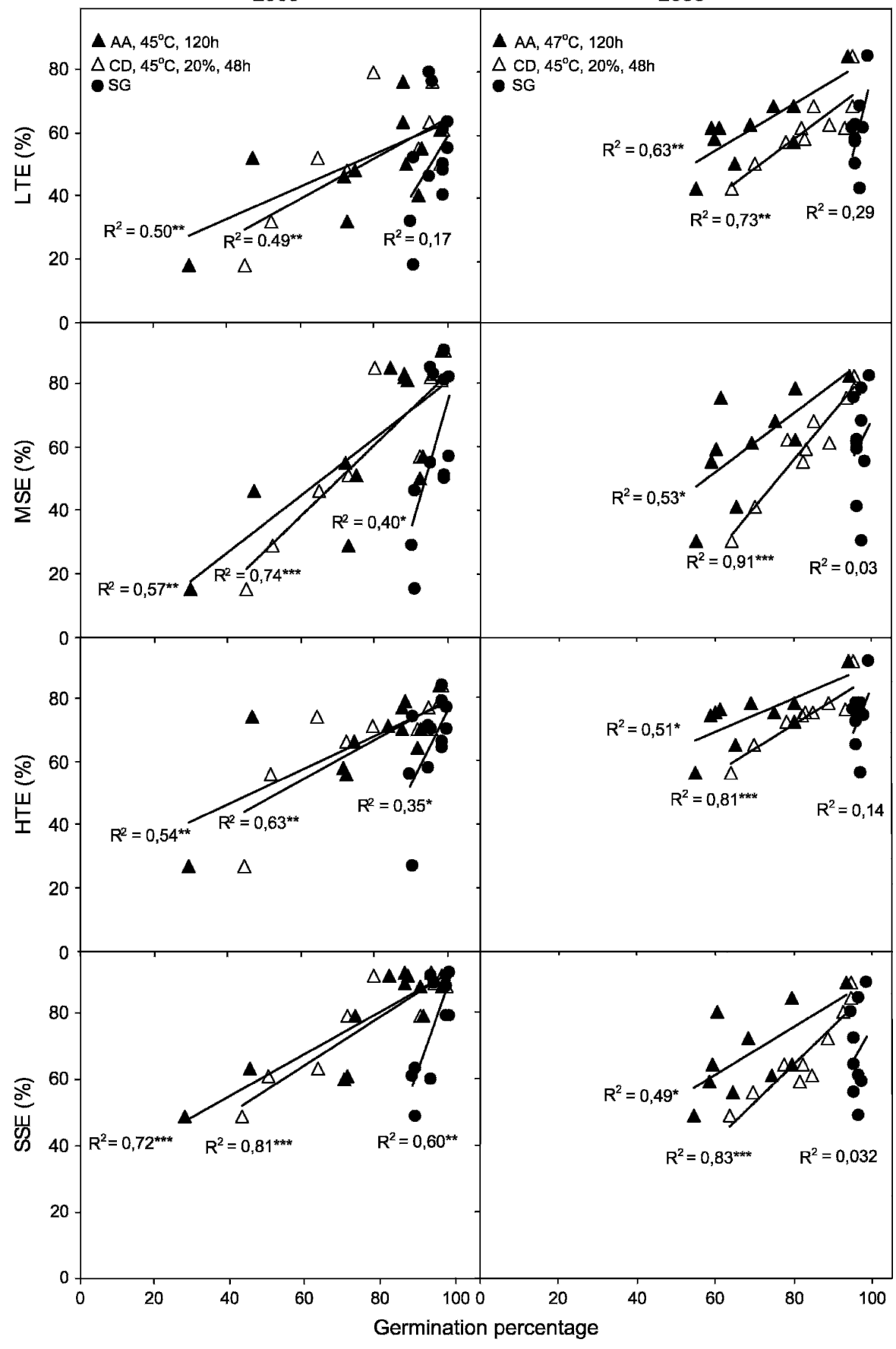

Fig. 1. Relationship between controlled deterioration (CD) at $20 \%$ moisture content (MC) for $48 \mathrm{~h}$ at $45^{\circ} \mathrm{C}$ $(\triangle)$, accelerated aging (AA) for $120 \mathrm{~h}$ at $45^{\circ} \mathrm{C}$ in 2005 and $47^{\circ} \mathrm{C}(\mathbf{\Delta})$ in 2006 and seedling emergence percentage at low temperature (LTE), mechanical (MSE), high temperature (HTE), and salt stresses (SSE) and laboratory germination (•) of melon seed lots in 2005 (left column) and 2006 (right column). $\mathrm{R}^{2}$ values were based on regression equations $\left({ }^{* * * * * * * *}\right.$ Significant at $P \leq 0.05,0.1$, and 0.01 , respectively).

$\left(120 \mathrm{~h}\right.$ at $\left.45^{\circ} \mathrm{C}\right)$, longer than the suggested period for most species (Hampton and TeKrony, 1995) is needed to get an ideal separation in melon seeds. More recently, Torres and Marcos-Filho (2005) used the traditional AA test at $41{ }^{\circ} \mathrm{C}$ for $72 \mathrm{~h}$ and were able to separate five melon seed lots in each of two cultivars. However, they used normal seedling evaluation in their work, and the range in five lots of each cultivar changed only between $76 \%$ and $92 \%$ in one cultivar and
$80 \%$ and $94 \%$ in the other. In our work, the range of the germination percentages was much larger in both aging tests (Tables 5 and $6)$. The physiological germination (2-mm radicle length) is easy to use in aging tests (Powell and Matthews, 2005). The capability for normal development seedling proceeds ahead of radicle emergence during the deterioration period and its evaluation can be subjective. In the same family but in different species, Dutra and Vieira (2006) reported that the combination of $41{ }^{\circ} \mathrm{C} / 96 \mathrm{~h}$ of the AA test can be used to evaluate the physiological vigor potential of pumpkin and zucchini seeds. In this study, seed lots were just ranked according to their germination percentage after aging. However, in our work, we also correlated vigor test results with field emergence.

Hampton and TeKrony (1995) suggested at 41 to $43{ }^{\circ} \mathrm{C}$ temperature and 24 to $72 \mathrm{~h}$ of aging in AA for a large number of species seeds. However, our results indicated that melon seeds are reasonably resistant to aging and require longer periods to get a clear separation. One hundred twenty hours of aging at 45 to $47^{\circ} \mathrm{C}$ in an accelerated aging test is required to differentiate melon seed lots successfully (Table 4). Germination after this aging environment was clearly related $\left(\mathrm{R}^{2}=0.49-0.72\right)$ to LTE, HTE, MSE, and SSE in both years (Fig. 1). A longer duration $(144 \mathrm{~h})$ at both temperatures of $45{ }^{\circ} \mathrm{C}$ in 2005 and $47^{\circ} \mathrm{C}$ in 2006 reduced germination percentages after aging to a greater extent, but the correlation values were reduced.

The stronger relationship of $\mathrm{CD}$ with emergence could well result from the greater accuracy of this test in comparison with the AA test. Controlled deterioration has precise control of seed moisture content with all seed lots having the same moisture content throughout the deterioration period. In contrast, the moisture content during AA increases during the test. Thus, some seed lots may increase in moisture more rapidly than others and hence age more in the 120-h period. This difference in moisture uptake from high humidity could occur even when seeds have the same initial seed moisture content.

In conclusion, both $\mathrm{CD}$ and $\mathrm{AA}$ tests can be used for predicting relative seedling emergence potential of melon seed lots in a range of stress conditions. The optimum aging environments on the bases of correlation values were found to be $45^{\circ} \mathrm{C}$ for $48 \mathrm{~h}$ with $20 \% \mathrm{MC}$ in $\mathrm{CD}$ and 45 to $47^{\circ} \mathrm{C}$ for $120 \mathrm{~h}$ in AA tests.

\section{Literature Cited}

Basak, O., I. Demir, K. Mavi, and S. Matthews. 2006. Controlled deterioration test for predicting seedling emergence and longevity of pepper (Capsicum annuum L.) seed lots. Seed Sci. Technol. 34:723-734.

Bates, M.D. and R.W. Robinson. 1995. Cucumbers, melons and watermelons, p. 89-97. In: Smartt, J. and N.W. Simmonds (eds.). Evolution of crop plants. 2nd ed. Longman Scientific \& Technical, Essex, UK.

Bennett, M.A., E.M. Grassbaugh, A.F. Evans, and M.D. Kleinhenz. 2004. Saturated salt accelerated aging (SSAA) and other vigor tests for vegetable seeds. J. Seed Technol. 1:67-74.

Delouche, J.C. and C.C. Baskin. 1973. Accelerated aging techniques for predicting the relative storability of seed lots. Seed Sci. Technol. 1:427-452.

Demir, I., S. Ermis, G. Okcu, and S. Matthews. 2005. Vigour tests for predicting seedling emergence of aubergine (Solanum melongena L.) seed lots. Seed Sci. Technol. 33:481-484. 
Demir, I., Y.S. Ozden, and K. Yilmaz. 2004. Accelerated aging test of aubergine, cucumber and melon seeds in relation to time and temperature variables. Seed Sci. Technol. 32:851-855.

Dutra, A.S. and V.D. Vieira. 2006. Accelerated aging test to evaluate seed vigor in pumpkin and zucchini seeds. Seed Sci. Technol. 34:209 214.

Foolad, M. and G.Y. Lin. 1997. Genetic potential for salt tolerance during germination in Lycopersicon species. HortScience 32:296300.

Hampton, J.G. and D.D. Bell. 1989. Seed quality and storage performance of prairie grass. N.Z. J. Agr. Res. 32:139-143.

Hampton, J.G., B.J. Brunton, G.M. Pemberton, and J.S. Rowarth. 2004. Temperature and time variables for accelerated aging vigour testing of pea (Pisum sativum L.) seeds. Seed Sci. Technol. 32:261-264.

Hampton, J.G. and D.M. TeKrony. 1995. Handbook of vigour test methods. Intl. Seed Testing Assn., Zurich, Switzerland.

Ibrahim, A., D.M. TeKrony, and D.B. Egli. 1993. Accelerated aging techniques for evaluating sorghum seed vigour. J. Seed Technol. 17: 29-37.
International Seed Testing Association. 2003 International rules for seed testing. Intl. Seed Testing Assn., Zurich, Switzerland.

Marshall, A.H. and R.E.L. Naylor. 1985. Seed vigour and field establishment in Italian ryegrass (Lolium multiflorum Lam.). Seed Sci. Technol. 13:781-794.

Matthews, S. 1980. Controlled deterioration: A new vigour test for crop seeds. In: Hebblethwaite P.D. (ed.). Seed production. Butterworths, London.

Matthews, S. 1993. Aging tests as a basis for the evaluation of seed quality. Acta Hort. 362:251-262.

Mavi, K. and I. Demir. 2005. Controlled deterioration for vigour assessment and predicting seedling growth of winter squash (Cucurbita maxima) seed lots under salt stress. N. Z. J. Crop Hort. Sci. 33:193-197.

Pesis, E. and T. Ng. 1983. Viability, vigor and electrolytic leakage of muskmelon seeds subjected to accelerated aging. HortScience $18: 242-244$

Powell, A.A. and S. Matthews. 1981. Evaluation of controlled deterioration, a new vigour test for crop seeds. Seed Sci. Technol. 9:633-640.

Powell, A.A. and S. Matthews. 2005. Towards the validation of the controlled deterioration vig- our test for small seeded vegetables. Seed Testing Intl. ISTA News Bul. 129:21-24.

Steiner, A.M. and M. Stahl. 2002. Vigour rating of rye varietal categories (Secale cereale L.) using controlled deterioration testing. Seed Sci. Technol. 30:219-222.

Strydom, A. and H.A. Van de Venter. 1998. Comparison of seed vigour tests for cabbage (Brassica oleracea var capitata). Seed Sci. Technol. 26:579-585.

TeKrony, D.M. 2003. Precision is an essential component in seed vigour testing. Seed Sci. Technol. 31:435-447.

TeKrony, D.M., D.B. Egli, and D.A. Wickman. 1989. Effect of corn seed vigour on no-tillage field performance: Field emergence and stand. Crop Sci. 29:1525-1528.

TeKrony, D.M., T. Shande, M. Rucker, and D.B. Egli. 2005. Effect of seed shape on corn germination and vigour during warehouse and controlled environmental storage. Seed Sci. Technol. 33:185-197.

Torres, S.B. and J. Marcos-Filho. 2005. Physiological potential evaluation in melon seeds. Seed Sci. Technol. 33:341-350.

Wang, Y.R., J.G. Hampton, and M.J. Hill. 1994. Red clover vigour testing - Effects of three test variables. Seed Sci. Technol. 22:99-105. 